\title{
THE MUSEU DEL DISSENY DE BARCELONA AS AN EXAMPLE OF PEDAGOGICAL INNOVATIVE PRACTICES
}

\author{
Marta García-Sampedro Fernández-Canteli \\ Noelia Fernández García* \\ Universidad de Oviedo
}

\begin{abstract}
Design has proved to be a discipline deeply connected to our daily lives. Its identification as a cultural heritage element is undeniable due to its wideranging values. In this sense, the Museu del Disseny de Barcelona has been promoting this artistic field since its creation in 2008. This museum has a relevant social and cultural function as it is the only design museum in Spain. Furthermore, the museum also stands out because of its innovative pedagogical programmes pointed to scholars, university students, families and groups of people with accessibility problems. The aim of this article is to present the Musseu del Disseny de Barcelona from an educational perspective, paying attention to its staff members, facilities, programmes and assessment. The 2018 museum annual report results are an example of its success. In order to accomplish this study, the authors have recently interviewed in-depth some members of the pedagogical team (Serveis Educatius).
\end{abstract}

Keywords: Design, Cultural Heritage, Museums, Pedagogy, Barcelona 
Overall, heritage is the set of tangible and intangible goods inherited from the past that citizens wish to transmit increasingly to future generations ${ }^{1}$. Furthermore, according to the definition established by the UNESCO World Conference on Cultural Heritage, held in Mexico in 1982, cultural heritage are the material and non-material works made by artists, architects, musicians and writers who express their creativity through their languages, rites, beliefs, places, historical monuments, literature, works of art, archives and libraries.

Among the institutions in charge of safeguarding and disseminating cultural heritage, museums stand out like one of the most broadly expanded and socially established worldwide entities. In accordance with the provisions of the ICOM (International Council of Museums) Statutes approved in Vienna in 2007, museums are permanent non-profit institutions at service of society and its development. They acquire, conserve, investigate, communicate and expose material and non-material heritage of humanity and its environment for the purposes of education, study and recreation ${ }^{2}$.

As mentioned, museum institutions must preserve cultural heritage elements and research about them, but these functions would be meaningless without considering museums social dimension. These days, museums act as cultural and social centres at the same time ${ }^{3}$. It is also worth highlighting the importance of the pedagogy and cultural action of museums. From the sixties onwards ${ }^{4}$, this museums and citizens started to consider this social and pedagogical perspective. Since then, museums have transformed themselves into multicultural spaces with relevant educational capacity. Hence, people do not perceive museums as elitist intellectual spaces anymore as they were in the past $^{5}$. Furthermore, these institutions have become spaces where learning merges with entertainment ${ }^{6}$ and collaboration between formal and non-formal education has commenced to be especially valued.

Some of the museums aims are to spread cultural heritage knowledge as an identity value of society ${ }^{7}$; to encourage values of respect and awareness of preservation; and to develop school-age public cognitive capacities, starting from 
the contemplation and understanding of the values and meaning of these elements ${ }^{8}$.

Due to the importance of the educational, social and cultural function of museums, it is desirable to promote the launching and development of Pedagogical or Education and Cultural Departments, also known as Didactic Cabinets, in them. These departments are in charge of the pedagogical orientation lines, methodologies and contents to fulfil the objectives as explained above. Museum conceives educational, social and cultural activities attending to recipients' age and background: Nursery level, Primary, Secondary or Higher Secondary students' education ${ }^{9}$.

Likewise, design, must be unquestionably understood as one of the pertinent elements that cultural heritage comprises, since it involves the use of different cultural and technical factors presented from different global visual aspects $^{10}$. Therefore, the need of founding design museums is indisputable in order to spread the relevance of its cultural, educational and aesthetic values. Consequently, it is essential to accomplish an in-depth analysis of the teaching aids used by these institutions to get to know the quality standards of their educational programmes ${ }^{11}$. In the Spanish case, a pioneering institution in the study and dissemination of the design discipline is The Museu del Disseny de Barcelona $^{12}$, whose pedagogical programming in collaboration with families, schools, universities and other institutions is the object of study of this article.

Considering Barcelona historical and close connection with design, the City Council launched an initiative to construct a museum whose central axis was Design ${ }^{13}$. In order to achieve this goal effectively, a team composed by different fields of expertise professionals worked on the fusion of the existing Applied Arts museum collections ${ }^{14}$. All these collections crystallized into one of much greater depth, in which visitors can discover design elements, in all their manifestations: Industrial Design, Eco-design, Fashion Design, Fashion Photography, Graphic Design, Historic Decorative Arts Design, and Product $\operatorname{Design}^{15}$. 
These collections represent what its director, Pilar Vélez, has called a common museological project and a flexible museography ${ }^{16}$. This flexibility comprehended as an intention to modify the permanent exhibitions every four or five years instead of creating a permanent sine die display. They get the most out of the museum's funds avoiding exhibiting the same pieces all the time.

According to Joana Mora, educator at the Museu del Disseny, museum's holdings are very extensive (Figs. 1-4) as they are made up of objects coming from the above-mentioned monographic museums spread across Barcelona in the past: el Gabinete de la Artes Gráficas, el Museo de Textil e Indumentaria, la Colección de Artes Decorativas or el Museo de la Cerámica ${ }^{17}$. On its part, the museum edifice has four floors that expose four permanent exhibitions at the same time, one per floor: decorative arts, product design, fashion, textiles and graphic design. Likewise, the museum organizes temporary monographic exhibitions every year. The last temporary exhibition dedicated to the designer Victor Papanek in collaboration with The Vitra Design Museum dealt with topics on social design, ecologies and functionality of objects in different social realities. Previously, the museum staff arranged one exhibition on the architect Adolf Loos' work focusing on furniture design and another on 20th century advertising graphic designers. Besides, the museum held an exhibition on David Bowie in 2017, coordinated by the Vitoria and Albert Museum of London.

The Museu del Disseny de Barcelona, conceived as a meeting place for all kinds of audiences, organises visits to permanent and temporary exhibitions as well as cultural and educational activities encouraged and developed by museum staff ${ }^{18}$. This versatility is perfectly suited to the diverse design manifestations and to the possibility of applying a transversal perspective when creating an expository discourse. 'For this reason, The Museu del Disseny must be seen as space not only for tourists but with a social function', says Joana Mora ${ }^{19}$. 'It must also be perceived as a place for consultation and research. Museums are educational contexts that supplement schoolwork ${ }^{20}$. 


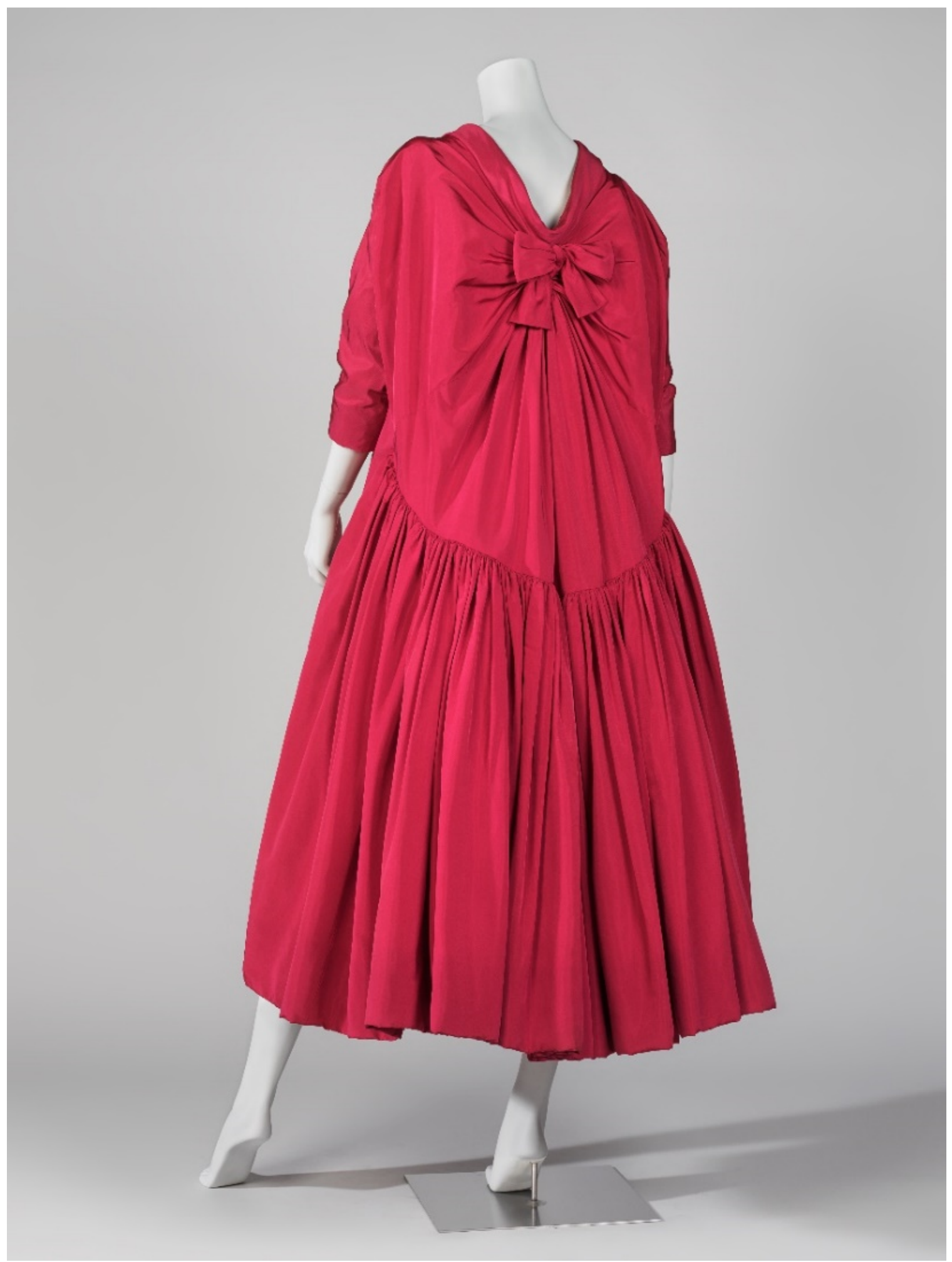

Fig. 1. Coat, Spring-Summer Collection 1955. Cristóbal Balenciaga (1895-1972). Donated by Carmen Mateu de Suqué, 1977. MTIB 104.656. Source: Museu del Disseny / Photograpgh: La Fotogràfica 
She believes that students' learning outputs are a complement to the official curriculum. They cannot simply be elite buildings for elite people visited not very frequently. Museums must be lively spaces in which visitors can seat, talk, contemplate, participate in activities and, above all, enjoy'.

MBM Architects created the museum building (Fig. 5) and Josep Cardús and Sílvia San Miguel coordinated its design project in 2008. It presents an industrial appearance due to the abundant use of metal and glass, in accordance with the city of Barcelona modern architecture style. It also respects the ideas of environmental quality, sustainability and energy sufficiency. It is divided into two different parts, a daylight semi-basement and a 14.5-meterhigh parallelepiped structure, which is also distributed into two floors and a mezzanine.

\section{MUSEUM LEARNING TEAM}

The Museu del Disseny de Barcelona is a public institution founded and ruled by Barcelona City Council. Its education department, called Serveis Educatius, is in charge of the organization of guided tours and specific workshops (nurtured by temporary and permanent exhibitions). This department works with schools, universities, families and disadvantaged groups of people with accessibility problems. The Serveis Educatius led by Carmina Borbonet, a Municipality of Barcelona officer with an extensive experience on this matter. She coordinates both Serveis Educatius and museum cultural events (courses, conferences, reading club, etc). The rest of the education team and up to nine part-time educators who work for Fragment, a private company in charge of this service ${ }^{21}$. As the museum offer is of highly varied nature, the staff team is also multidisciplinary. Museum educators are university graduates in Humanities, Fine Arts, Product and Industrial Design and Graphic Design. This team designs and implements all the educational activities in the museum. 


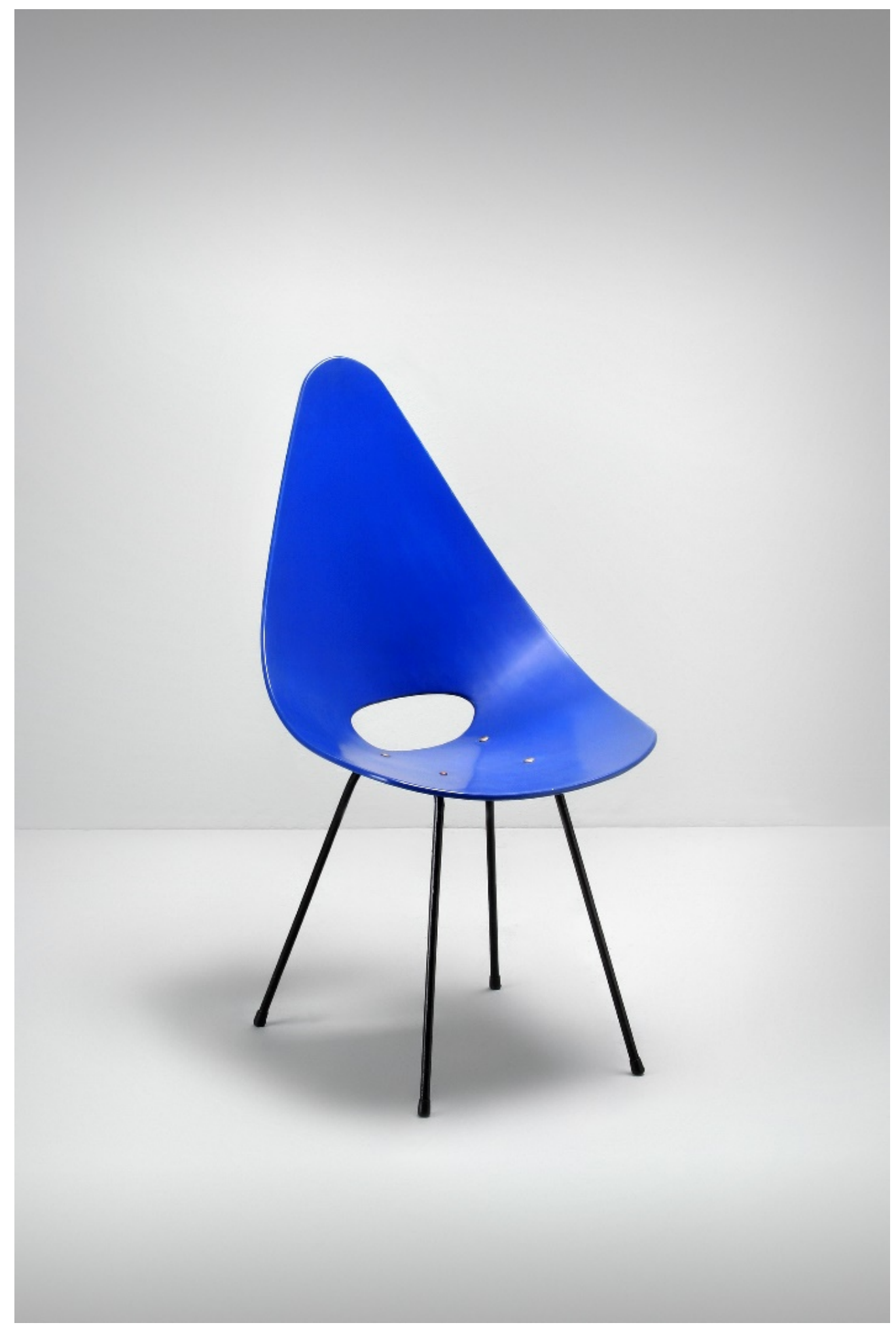

Fig. 2. Pedrera Chair, 1955. Francisco Juan Barba Corsini (1916-2008). Donated by Galería H2O, 1994. MADB 135.431. Source: Museu del Disseny / Photograph: Estudio Rafael Vargas 


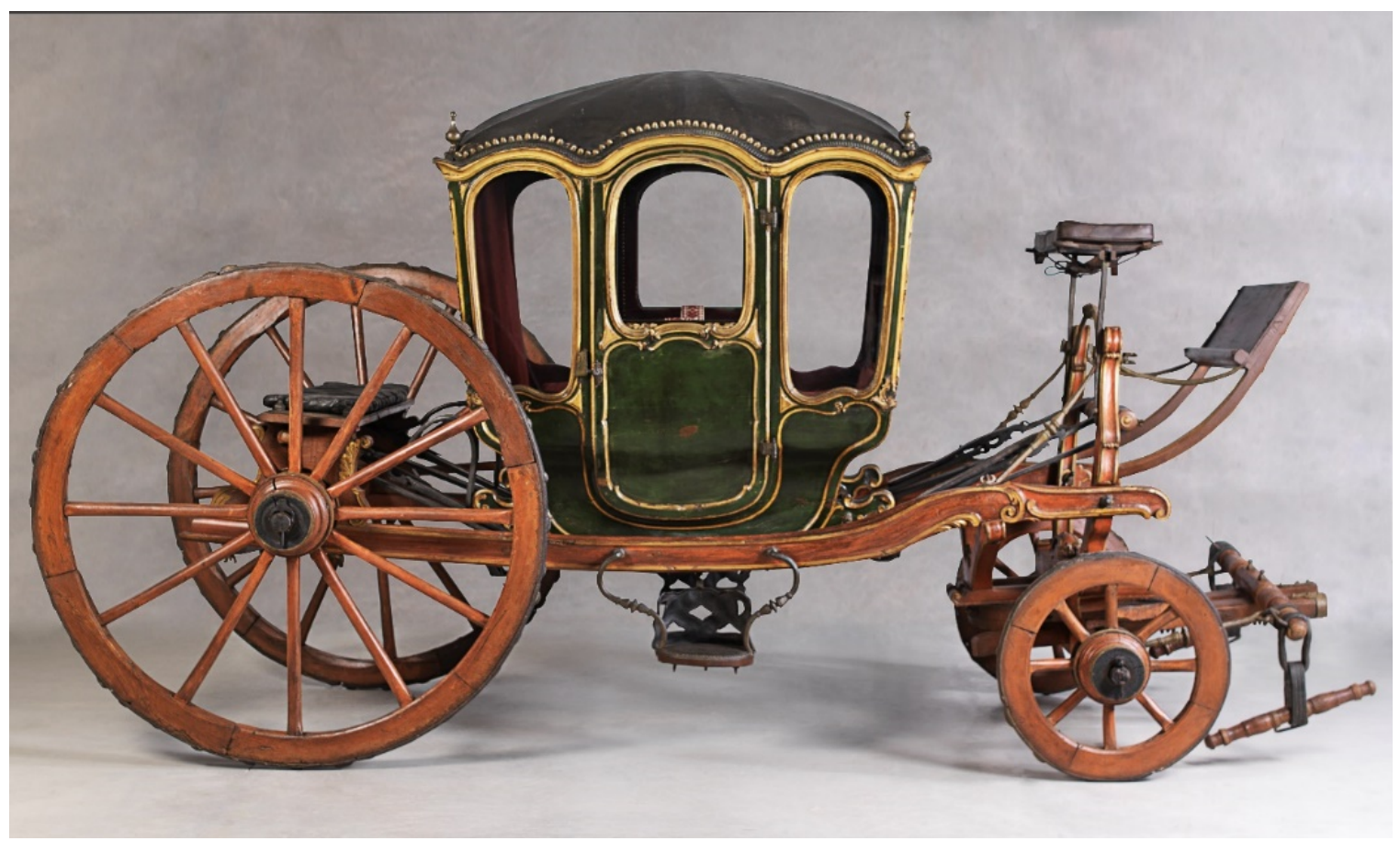

Fig. 3. Berline. Mallorca, mid-18th century. Acquisition, 1899. MADB 2.952. Source: Museu del Disseny / Photograph: La Fotogràfica

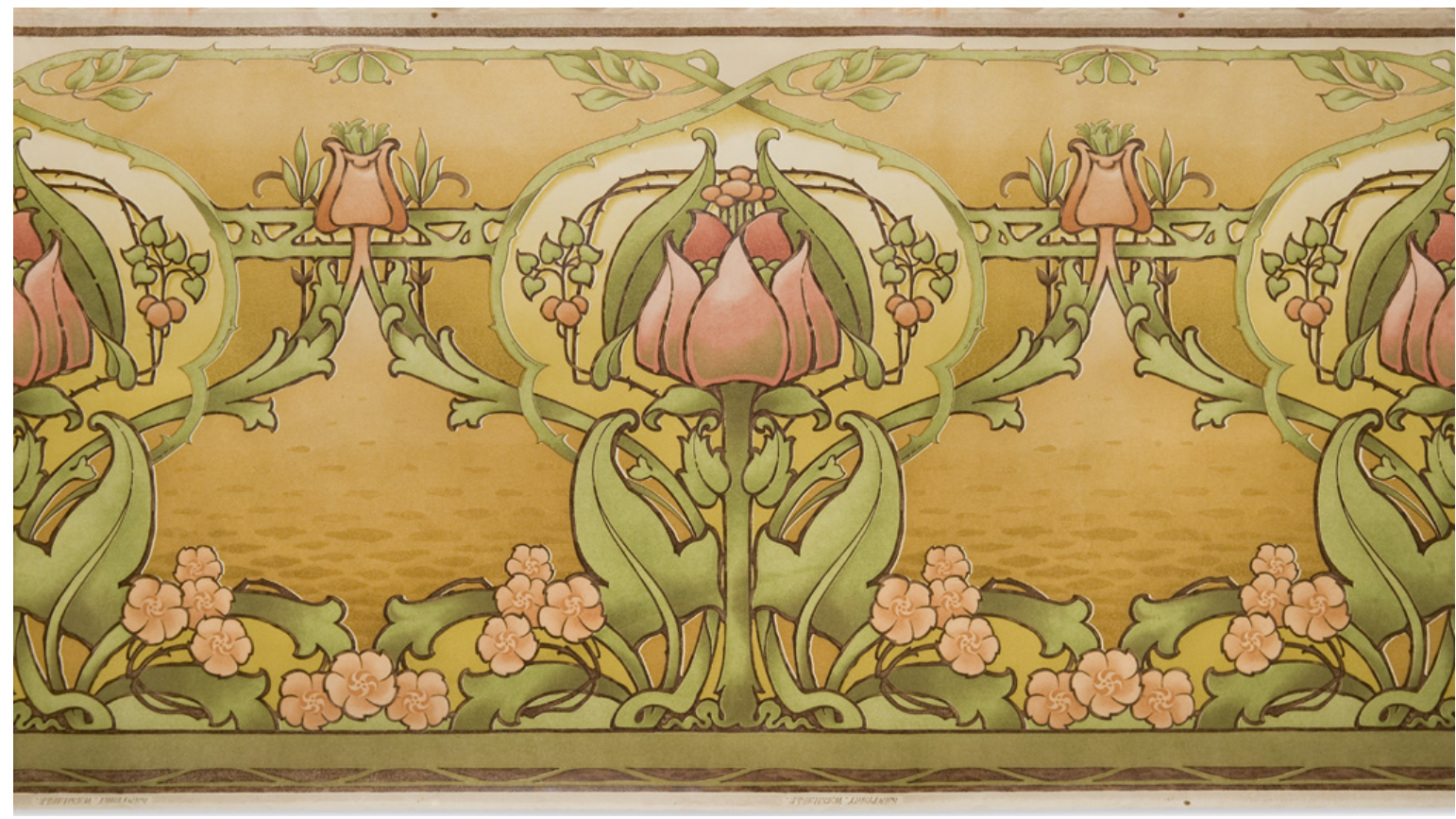

Fig. 4. Wallpaper. United Kingdom, 1890. Silver Studio Collection. GAGB 9593/14. Source: Museu del Disseny / Photograph: Xavi Padrós 


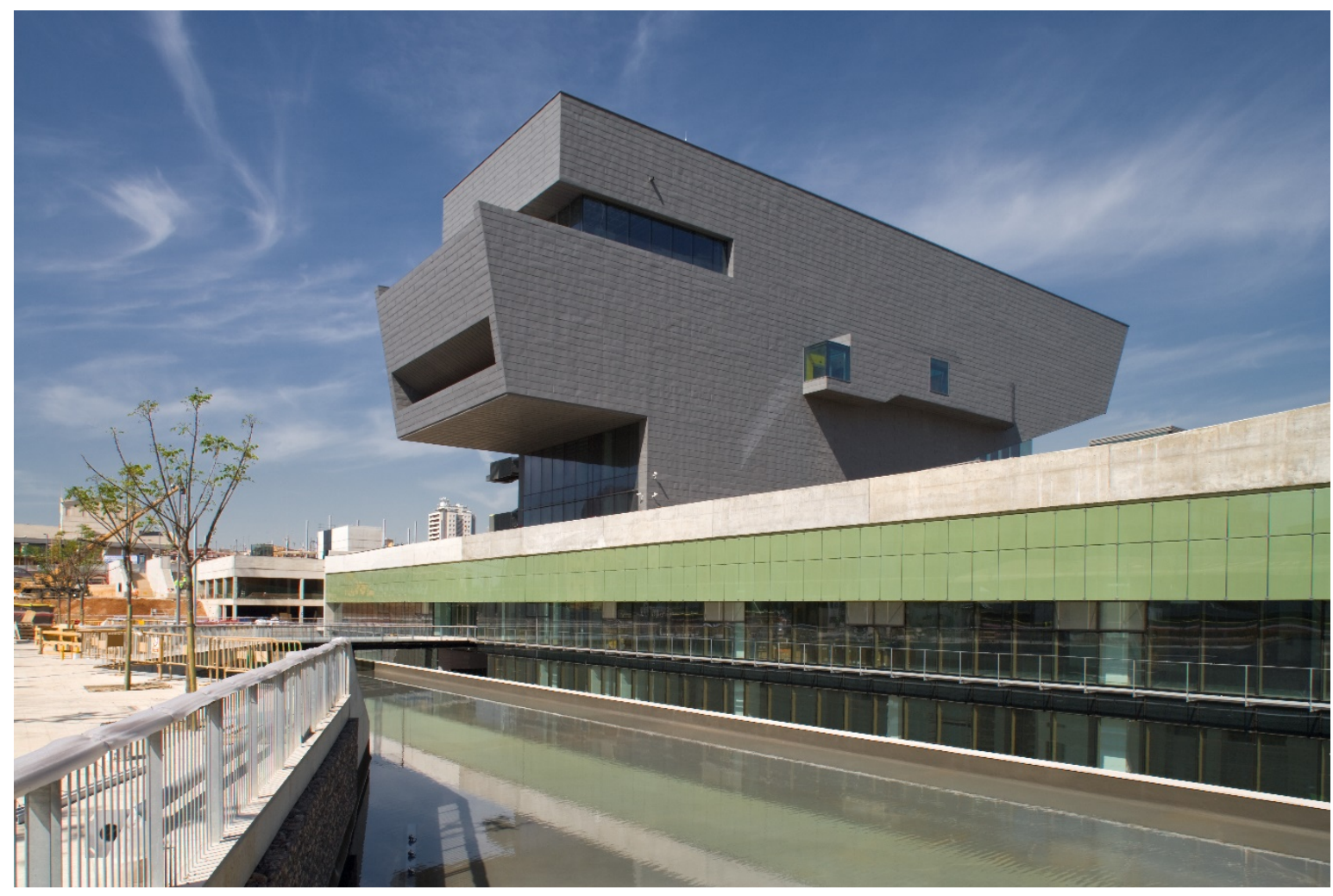

Fig. 5. Disseny Hub Barcelona. Source: Museu del Disseny / Photograph: Lourdes Jansana

Educators are mediators between the museum and its visitors and try to adapt museum cultural and educational proposals to the audience necessities. That is the reason why museum organises such a wide variety of assorted guided tours and workshops. Consequently, very well-trained educators are able to attend all sorts of activities and audiences' necessities.

\section{MUSEU DEL DISSENY PEDAGOGICAL PROGRAMMES}

Carmina Borbonet explicates that although museum facilities are magnificent, they are becoming rather small, since visits and workshops demanded by schools, universities and groups of people with accessibility problems are increasing substantially ${ }^{22}$. In this moment, two of the museum rooms are dedicated to workshops, and a conference room has recently been adapted to these activities, too.

As expected, museum staff members share both an ample concept of the term education and an audience's demands concern. The number of museum 
visitors and workshop participants is increasing significantly every year. In 2018, 231,316 people visited the museum. Up to 42,356 took part on several museum activities ${ }^{23}$. In the same year, 5,601 school pupils and teenagers attended at seven different sorts of workshops and activities (240 sessions). The museum's scope of action is not only Primary and Secondary Schools but also Intermediate and Advanced Vocational Training Cycles, Design Schools and different Faculties.

As one of the museum most desirable objectives was to reach family audiences, a specific programme for them obtained excellent results. In 2018, 4,020 people attended to six family activities (103 sessions) and three weekend workshops offered from October to April (1 on Saturdays and 2 on Sundays). In May and September, there is only one workshop on Sundays. These family activities allow children and adults to work together in teams focusing on one of the museum exhibitions. The main idea of these workshops is to show participants that good design is the one, which helps the highest number of people. In July, the museum generally offers some "day camps" for children from six to twelve years (9.30 am-5 pm) and for teenagers from $13-17$ years $(9.30 \mathrm{am}$ $2 \mathrm{pm})$. These camps last for one week in the case of children and two weeks in the case of the teenagers. In August, the museum does not offer any workshop. Additionally, museum proposes some special programmes for children and students at Christmas holidays. In 2018, 780 children and teenagers participated in six different activities (33 sessions) in this museum.

\section{Workshops for School Audiences ${ }^{24}$}

Joana Mora assesses that the relationship between the museum and the education centres, focused on the spread of heritage values and children and youngster' s training, is extremely close and productive ${ }^{25}$. In this sense, one of the museum workshops aims is to connect with students' interests, realities and everyday life, emphasizing the fact that design is everything and it is everywhere (Fig. 6). 
'When this is accomplished, students feel incredibly creative and expressive. It is very stimulating to see how they can learn from everyday life experiences and from the objects, surrounded by. Museum workshops relate daily routines, such as having breakfast, with the process of design. This way, daily experiences are connected to the theory of design'26. In Mora's opinion, the most relevant aspect of museum visits is what people take from the museum to their homes: memories, reflections and learning from a design perspective.

Mora explains that 'students who are not very successful in traditional learning contexts often obtain better results in non-formal spaces because they are allowed to create, think and research autonomously. In some cases, they behave more resolutely because they develop visual, practical or manipulative skills. Hence, most of the students feel highly motivated when developing activities out of the school'27. The fact of escaping from school routines and live new learning experiences in non-formal spaces, such as the museum, is always an achievement.

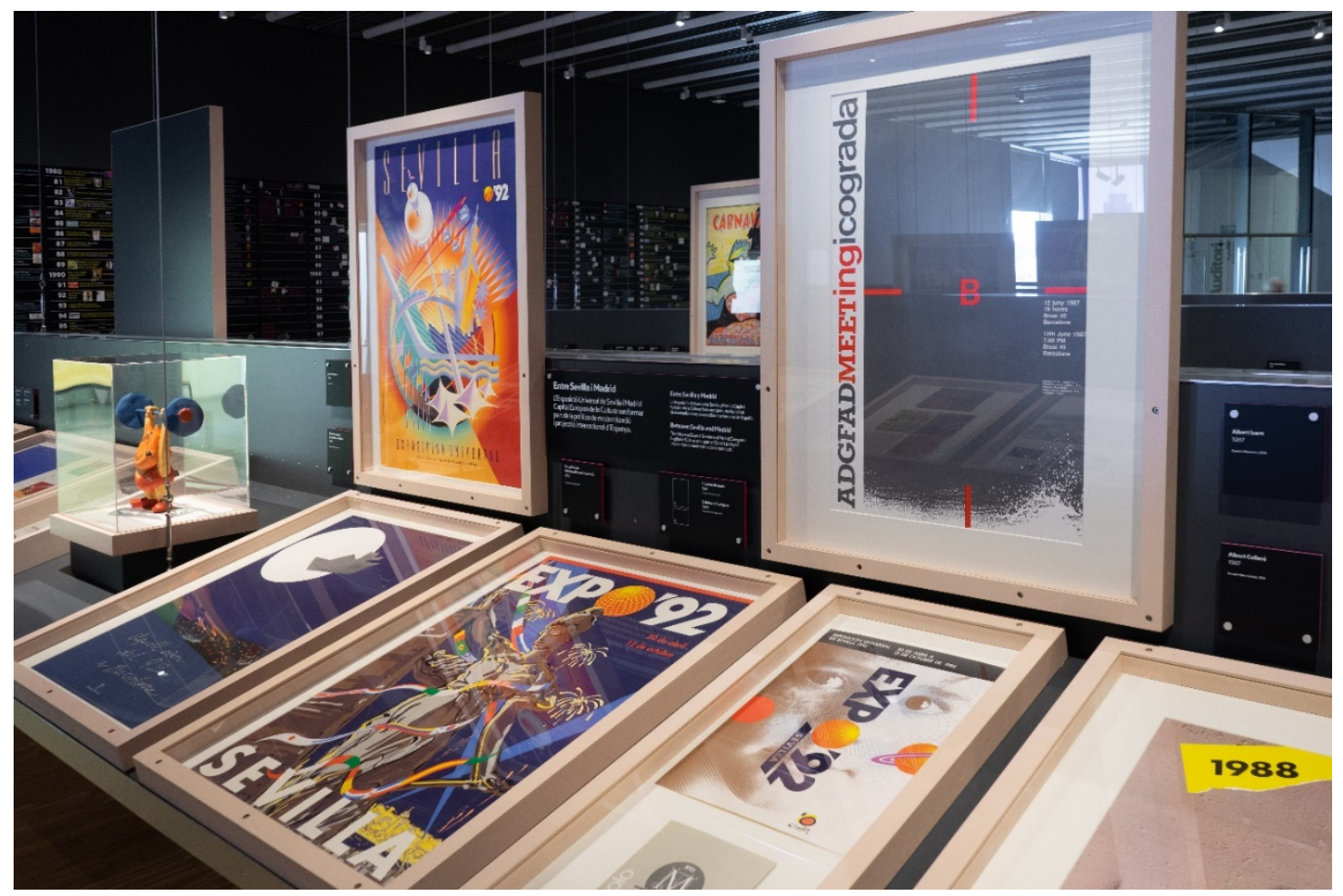

Fig. 6. Exhibition ‘Diseñas o trabajas? La nueva comunicación visual. 1980-2003’. Source: Museu del Disseny / Photograph: Dizy Díaz 
Another significant aspect related to the education centres and the museum is the way through which they contact. In Barcelona, the Institut Municipal d'Educació (IMEB) ${ }^{28}$, created in 1993, owns a database, which includes all the cultural institutions activities aimed to schoolchildren and teenagers. The IMEB spreads this information so that schools can select the activities they want to take part in. The IMEB also arranges an annual meeting in which cultural institutions present their offerings. The relationship between IMEB, schools and cultural institutions has been fundamental for the development and improvement of the out-of-schools programmes in Barcelona. Because of this fruitful collaboration, both schools and institutions have started to expand specific collaborative projects attending to schools demands and necessities. In 2018, the number of pupils and students who visited and participated in museum programmes was 5,601 what implies a $13.2 \%$ of the visitors $^{29}$.

Most of the activities developed by Museu del Disseny are evolved in the museum facilities, but sometimes, when long-term projects ${ }^{30}$ are implemented, museum educators move to schools to do some teacher training or to present workshops (to teachers, students or parents).

The language ordinarily used in museum workshops is indistinctly Catalan or Spanish although they have implemented some special activities for university students in English and French.

\section{Accessibility programmes}

These programmes focused on visitors with social, cognitive or physical accessibility problems, include adapted guided visits and workshops. The museum designed these programmes in collaboration with Apropa Cultura ${ }^{31}$. This Catalan entity promotes cultural inclusion, spreads information on events and intermediates among collectives of people with special needs (people with physical and/or mental disabilities and people in risk of social exclusion) and 
cultural institutions to promote cheaper or free access to cultural entities such as museums, theatres or auditoriums.

These museum programmes are flexible in content, timing, and development and they are completely adapted to visitors' necessities and interests (Fig. 7). They regularly last for 90 minutes approximately.

\section{WORKSHOPS METHODOLOGY}

All of the workshops imparted at the museum follow the same structure no matter which they addressed them. Visits, in general, share the same structure: welcoming, dynamical exhibition visit and activities at the workshops. Although this is the typical scheme, all the arranged activities have different aims and contents.
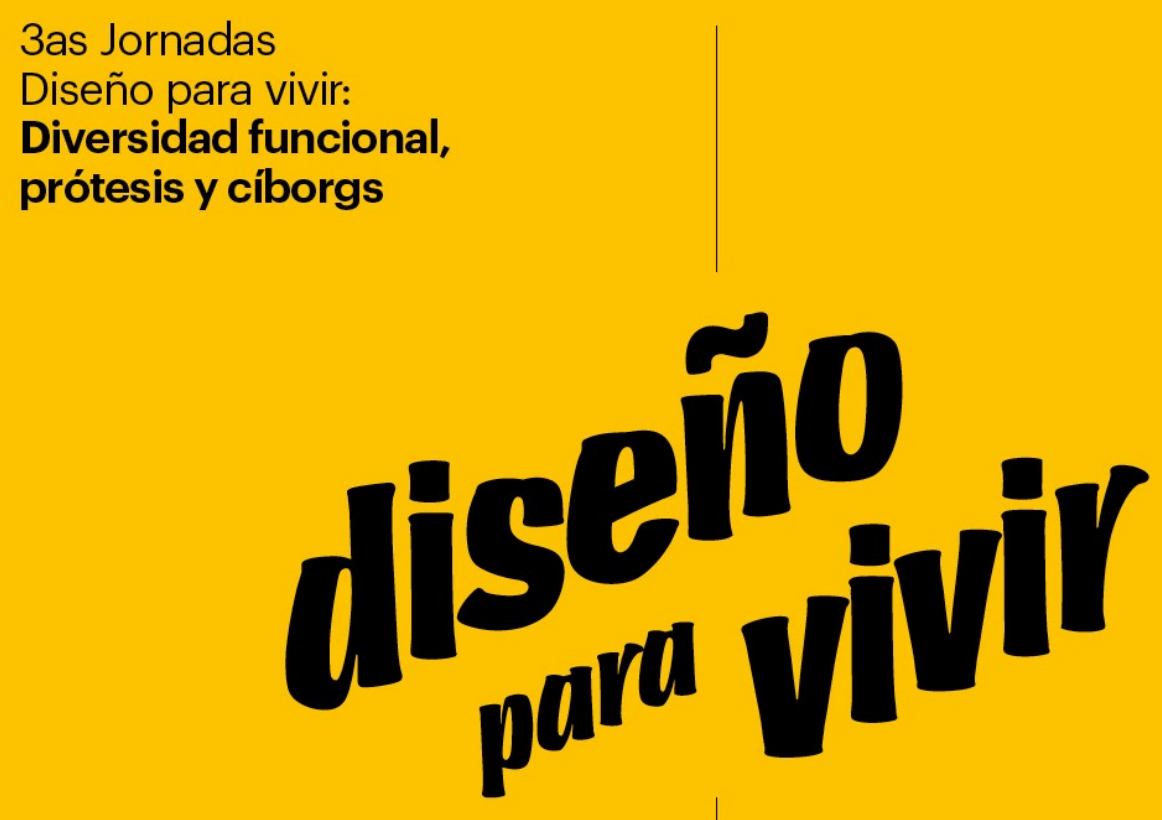

\section{1,22 y 23.11.2018 Museu del Disseny}

Fig. 7. Poster of the conference 'Diseño para vivir: diversidad funcional, prótesis y cíborgs' Source: Musseu del Disseny 
Museum heads consider fundamental to combine visits with manipulative and practical activities, during which, visitors design and create different products following Design Thinking process. Design thinking is the methodology followed by designers applied to any sort of individual or group learning process. This methodology follows several steps: empathising with the people and their necessities; finding solutions for the presented problems; sketching ideas; making models or prototypes and finally, testing these models. If any of these mentioned stages does not work successfully, the process starts again. This methodology ensures the product's utility, practicality and aesthetic aspect. During workshops, visitors are encouraged to rethink objects people have in their homes ${ }^{32}$ and to analyse their usages in relation to their necessities: washing your teeth, wash your clothes, eating, etc.

In the case of Primary Schools Programmes, educators start workshops defining designer's tasks and explaining concepts such as empathy, ergonomics, materials or functionality, as a rule. Every workshop space has four tables around which several children work. Every table becomes an island with different inhabitants and respective problems and necessities. The island map stamped on a sort of plastic mantelpiece that covers the tables. There are four islands: elderly people, children, very tall people and disabled people. Every island owns a list of inhabitants' necessities to make children empathise with their needs. Knowing the island circumstances, children have to solve citizens' problems applying the Design Thinking method, explained before.

\section{PEDAGOGICAL ASSESSMENT PROCESS}

The museum pedagogical assessment process presents two different perspectives. On the one hand, museum provides visitor teachers with assessment rubrics, and on the other hand, an internal self-assessment process that involves all the learning team members.

Carmina Borbonet collaborated in the elaboration of an assessment rubric for heritage spaces and museums educative departments with a service learning 
community ${ }^{33}$. They designed a 15 items rubric with questions for the teachers, three of which were employed by The Musseu del Disseny in its assessment process. The first question asks if the museum visit relates to any specific aim. The second question enquires if the visit has been a stimulus for visitors' curiosity, creativity and reasoning ability, and finally, the third question wants to know if the visit connects with visitors' previous knowledge and experiences and if the visit structure is coherent. Museum coordinators consider these questions as rather generic but fundamental to analyse museum pedagogical performance.

The Museu del Disseny follow a self-assessment process, at least, once at a term. During these internal assessment meetings, a deep reviewing, in which all the received rubrics are checked, is carried out. Accordingly, museum staff revises pedagogical programmes very thoroughly and make modifications as soon as they detect deficiencies.

\section{CONCLUSION}

The Museu del Disseny in Barcelona results in a remarkably interesting body in terms of dissemination of culture and heritage for children, youngsters and adults due to the various programmes performed by the institution in collaboration with schools, universities, families or other diverse groups.

Not only the flexible museography, but also the thorough work developed by the professionals in the Didactic Cabinet of the museum (Serveis Educatius), leads to the production of multiple pedagogical activities, such as guided tours or workshops, focused on the permanent and temporary exhibitions. These activities allow different profiles of public to learn and go in depth in design and its categories. They also let visitors be conscious of the importance of this field in history and in their current lives. At the same time, the institution implements innovative methodologies based on the Design Thinking process all throughout its pedagogical programmes. In addition, the partnership between 
schools and museum reinforces every year with the emergence of new collaborative projects.

In summary, it can be said that The Museu del Disseny pedagogical practices are a national referent because of the implementation of innovative methodologies and resources and its continuous spread of design knowledge. The figures in terms of quantity of visitors shown in this article confirm the success of the approaches developed by the museum.

\section{NOTES}

\footnotetext{
${ }^{1}$ María Pilar García Cuetos, El patrimonio cultural. Conceptos Básicos (Zaragoza: Prensas Universitarias de Zaragoza, 2012), 16-17.

2"Museum Definition by the 22nd General Assembly in Vienna, Austria, on 24 August 2007", International Council of Museums, https://icom.museum/es/actividades/normas-y-directrices/definicion-del-museo/ (accessed January 6, 2020).

${ }^{3}$ Francisco Javier Zubiaur Carreño, Curso de Museología (Gijón: Trea, 2004), 307.

${ }^{4}$ Luis Alonso Fernández, Museología y Museografía (Barcelona: Ediciones del Serbal, 1999)

${ }^{5}$ Marta García-Sampedro and Sue Gutiérrez Berciano "El museo como espacio multicultural y de aprendizaje: algunas experiencias inclusivas", Liño. Revista Anual de Historia del Arte 24 (2018): 119-121.

${ }^{6}$ Marta García-Sampedro and Sue Gutiérrez Berciano "El museo como espacio multicultural y de aprendizaje: algunas experiencias inclusivas", 118.

${ }^{7}$ Sue Gutiérrez Berciano and Roser Calaf, "La Evaluación Pedagógica: una realidad en el museo", Pulso 36 (2013): 38.

${ }^{8}$ Francisco Javier Zubiaur Carreño, Curso de Museología, 278-279.

${ }^{9}$ Francisco Javier Zubiaur Carreño, Curso de Museología, 289-290.

${ }^{10}$ Ana María Cortijo, "El Diseño como Patrimonio", PH. Especial Monográfico: Patrimonio y desarrollo 42 (2003): 4.

${ }^{11}$ Roser Calaf Masach, Iratxe Gillate and Sue Gutiérrez Berciano, "Transitando por la evaluación de los Programas Educativos de Museos de Arte del Proyecto ECPEME”, Educatio Siglo XXI 33, no. 1 (2015): 133.

12 "Métodos y estrategias para el incremento patrimonial. La creación y el crecimiento de las colecciones en el Museo del diseño de Barcelona", Teresa Bastardes Mestre, (accessed September 23, 2019).

${ }^{13}$ Pilar Vélez Vicente, "El Museu del Disseny de Barcelona: el patrimoni, un recurs al servei del coneixement, el debat i els reptes socials", Revista de museus 2 (2017): 81.

14 "Métodos y estrategias para el incremento patrimonial. La creación y el crecimiento de las colecciones en el Museo del diseño de Barcelona", Teresa Bastardes Mestre, (accessed September 23, 2019).

${ }^{15}$ Pilar Vélez Vicente, "El Museu del Disseny de Barcelona: el patrimoni, un recurs al servei del coneixement, el debat i els reptes socials", 85.

${ }^{16}$ Pilar Vélez Vicente, "El Museu del Disseny de Barcelona: el patrimoni, un recurs al servei del coneixement, el debat i els reptes socials",79.

${ }^{17}$ Mora, Joana. Personal phone interview with Marta García-Sampedro. April 17, 2020.

${ }^{18}$ Pilar Vélez Vicente, "El Museu del Disseny de Barcelona: el patrimoni, un recurs al servei del coneixement, el debat i els reptes socials",89.

${ }^{19}$ Mora, Joana. Personal phone interview with Marta García-Sampedro. April 17, 2020.

${ }^{20}$ Mora, Joana. Personal phone interview with Marta García-Sampedro. April 17, 2020.
} 
${ }^{21}$ This company won the public competition to lead the organization and development of the museum's educational activities.

${ }^{22}$ Borbonet, Carmina. Personal phone interview with Marta García-Sampedro. April 11, 2020.

23" "Memória anual 2018", Museu del Disseny de Barcelona, https://ajuntament.barcelona.cat/museudeldisseny/sites/default/files/memoria_2018_museu_del_disseny.pdf (accessed March 30, 2020).

${ }^{24}$ Activities for school students: "El abecé del diseñográfico. Color, tipografía y composición" for primary pupils. "Pensar con los ojos y mirar con el cerebro. Las herramientas del diseñador gráfico" for secondary and vocational training students.

${ }^{25}$ Mora, Joana. Personal phone interview with Marta García-Sampedro. April 17, 2020.

${ }^{26}$ Mora, Joana. Personal phone interview with Marta García-Sampedro. April 17, 2020.

${ }^{27}$ Mikel Asensio, "El aprendizaje natural, la mejor vía de acercarse al patrimonio", Educatio Siglo XXI 33 no. 1 (2015): 55-82

${ }^{28}$ For further information, visit IMEB: https://ajuntament.barcelona.cat/educacio/es/quienes-somos-y-quehacemos

29"Memória anual 2018", Museu del Disseny de Barcelona, https://ajuntament.barcelona.cat/museudeldisseny/sites/default/files/memoria_2018_museu_del_disseny.pdf (accessed March 30, 2020).

30 "En Residencia. Creadores en los Institutos de Barcelona”, Instituto Maria Espinalt. "Trabajo Globalizado de Propuesta Externa", Instituto Doctor Puiguert. "Naturaleza y ciudad" ICUB (Instituto de Cultura de Barcelona), el Consorcio de Educación y La Mandarina de Newton. "Patrimonio 'm. Col-lecions 2018-2019" L'Escola Catalònia.

${ }^{31}$ For further information, visit Apropa Cultura: https://www.apropacultura.cat/

${ }^{32}$ This workshop is called "Pequeños problemas, grandes soluciones".

${ }^{32}$ Borbonet, Carmina. Personal phone interview with Marta García-Sampedro. April 11, 2020.

Received: 2020-06-16

Revised: 2020-07-09

Accepted: 2020-07-14 